\title{
IN VITRO GENOTOXICITY OF SETTAT TOWN LANDFILL LEACHATE, MOROCCO
}

\author{
Loubna AMAHDAR ${ }^{1}$, Abdellah ANOUAR ${ }^{1}$ Bouchra ABABOU ${ }^{1}$, Luc VERSCHAEVE ${ }^{2}$, \\ and Abderraouf HILALI ${ }^{1}$ \\ Agrofood and Health Laboratory, Faculty of Science and Technology, University Hassan I, Settat, Morocco ${ }^{1}$, \\ Laboratory of Toxicology, Scientific Institute of Public Health, Brussels, Belgium ${ }^{2}$
}

Received in October 2008

Accepted in February 2009

\begin{abstract}
With the increasing use of landfill sites, leachates produced by uncontrolled waste disposal have became a serious threat for the aquatic environment. The aim of this study was to evaluate the genotoxicity of leachate and of well water sampled close to the town of Settat in Morocco using the micronucleus test and proliferation kinetics of human peripheral blood lymphocytes in vitro. We also analysed a number of physical and chemical parameters, including $\mathrm{pH}, \% \mathrm{O}_{2}$, chemical oxygen demand (COD), $\mathrm{HCO}_{3}{ }^{-}, \mathrm{Ca}^{2+}$, $\mathrm{Mg}^{2+}, \mathrm{Cl}^{-}$, and conductivity.

The analysis showed much higher levels of nearly all parameters than the Moroccan standard. Increased micronucleus frequencies were also found for both leachate and well water. Preliminary results indicate that both types of water are genotoxic and pose environmental and human health risk.
\end{abstract}

KEY WORDS: dose-effect, lymphocyte, micronucleus, physico-chemical properties, proliferation index, toxicity

Solid waste management is a crucial environmental problem today, with its amount continuously increasing (1). In Morocco, the most usual way to dispose of waste is still the dump. As waste changes physically, chemically, and biologically, leachates are formed that enter and interact with the environment (2). This is how leachates containing high amounts of pollutants $(3,4)$ can contaminate ground and surface waters and affect biodiversity of aquatic ecosystems, contaminate food chains, and pose a risk to human health. Several in vitro and in vivo studies of the ecotoxicological impact of environmental chemicals have confirmed that many chemicals identified at city dumps and in leachates have a genotoxic and carcinogenic potential (5-12). Determination of the chemical composition and the genotoxic potential of wastewaters, surface, and ground waters is considered crucial for environmental protection and public health (13). It is also important to assess the toxicity of complex mixtures such as leachates or of effluents, as current chemical checks can not reliably identify the risk for human health and wildlife. Instead, biomonitoring studies can give comprehensive information about bioeffects which may not be easily identified with specific chemical analyses (14). This in vitro study investigated the potential genotoxicity of a leachate from a city dump by exposing human white blood cells to increasing amounts of leachate and ground water sampled near the landfill site.

\section{STUDY DESIGN AND METHODS}

The landfill site is situated $7 \mathrm{~km}$ away from the outskirts of the Moroccan town of Settat and $2 \mathrm{~km}$ to the west from the road connecting Settat to Oulad Said at $438 \mathrm{~m}$ above sea level. With a surface of some 20 ha it has been in uncontrolled use since 1984. It receives approximately $170 \mathrm{t}$ of untreated domestic, industrial, and hospital waste per day. Leachate is formed and 
drained under the heaps of waste threatening to contaminate local ground waters. In order to evaluate the level of contamination of local ground waters and to estimate their genotoxic potential, we conducted a physicochemical and cytogenetic analyses of leachate and well water sampled close to the landfill site.

\section{Sampling}

We sampled $1500 \mathrm{~mL}$ of leachate and well water from a well located $10 \mathrm{~m}$ away from the landfill site. Samples were kept in polyethylene bottles and transported to the laboratory at $4{ }^{\circ} \mathrm{C}$.

\section{Physicochemical analysis}

Physicochemical analyses of leachate, well water, and control samples were performed according to standard protocols $(15,16)$.

\section{Cytogenetic analysis}

Venous blood $(10 \mathrm{~mL})$ was collected in a sterile heparinised tube from a healthy female donor (age 27 years, non-smoker) who gave informed consent for participation in the study. Cells were then cultured according to a slightly modified standard protocol for the micronucleus (MN) test (17). Briefly, $0.5 \mathrm{~mL}$ of whole blood was cultured under sterile conditions in a culture tube containing $5 \mathrm{~mL}$ of RPMI 1640 medium supplemented with $15 \%$ foetal calf serum (Sigma-Aldrich Chemie $\mathrm{GmbH}$ ), $1 \%$ streptomycinpenicillin (Sigma-Aldrich Chemie $\mathrm{GmbH}$ ), and $1 \%$ phytohaemagglutinin (CAS \# 14930-96-2, SigmaAldrich Chemie $\mathrm{GmbH})$. Leachate or well water were added in increasing volumes (from $100 \mu \mathrm{L}$ to $1500 \mu \mathrm{L}$ ) to the culture tubes. Volumes were increased essentially to determine those suitable for future experiments, but also to avoid confounding cytotoxic effects caused by other factors such as changes in osmolarity. We used tap water as negative control, since it is the most consumed type of drinking water.

Cell cultures were incubated in humified atmosphere with $5.0 \% \mathrm{CO}_{2}$ at $37^{\circ} \mathrm{C}$. Cytochalasin B (CAS \# 900897-3, Sigma-Aldrich Chemie $\mathrm{GmbH}$ ) was added to the cultures at the final concentration of $4 \mu \mathrm{g} \mathrm{mL}^{-1}$, at 44 h. Cultures were harvested after a total cultivation time of $72 \mathrm{~h}$ following a hypotonic shock $\left(7.5 \mathrm{mmol} \mathrm{L}^{-1}\right.$ $\mathrm{KCl})$ and fixation with acetic acid : methanol (1:3). Slides were stained for light microscopy (x400) with $5 \%$ Giemsa. Each was examined for the presence of micronuclei using the criteria of Fenech et al. (18).
Our goal was to investigate 1000 binucleated cells per sample, but in some instances this amount was not reached (see Table 2).

The proliferation index (PI) was calculated according to the following formula (19):

$$
\mathrm{PI}=\frac{\left(1 \times \mathrm{N}_{1}\right)+\left(2 \times \mathrm{N}_{2}\right)+\left(3 \times \mathrm{N}_{3}\right)+\left(4 \times \mathrm{N}_{4}\right)}{1000 \text { cells analysed }}
$$

where $\mathrm{N}_{1}-\mathrm{N}_{4}$ is the number of cells with 1-4 nuclei, respectively.

\section{Statistical analysis}

The statistically significant difference between the control and treated samples was determined using the ANOVA.

\section{RESULTS AND DISCUSSION}

In addition to residues from bacterial activity, dump leachates contain a mixture of organic and inorganic substances that can react with each other. Sooner or later they will enter ground water (20). This was confirmed by our physicochemical analysis, especially for calcium, magnesium, and chloride concentrations. COD, conductivity, and alkalinity were also very high both in the leachate and in the well water (Table 1). Our study also confirmed that due to migration, leachate constitutes a very important source of pollution, especially for the aquatic environment (ground and surface waters) (21).

MN frequency and lymphocyte proliferation index gave us an insight into the genotoxic potential of the leachate in vitro. The MN test is a well-known and validated endpoint that can predict increased cancer risk in a human population (22). This test has an advantage over tests with bacteria such as the Ames assay, which are not sensitive enough for water and soil leachate genotoxicity evaluations, especially when heavy metal contamination is anticipated $(12,23)$. Nowadays the MN test is sometimes accompanied by counting apoptotic and necrotic cells, nuclear buds, and nucleoplasmic bridges (the cytome assay) (24).

Our study is a preliminary investigation limited to the "classical" MN test alone. We investigated a dose-effect relationship based on the MN frequency and changes in the proliferation index of lymphocytes treated with increasing volumes of leachate, well water, and tap water. 
Table 2 shows that MN frequency increased with leachate volume. At an intermediate volume of $800 \mu \mathrm{L}$ we found up to $48 \mathrm{MNs}$ per 1000 binucleated cells. However, in samples treated with higher leachate volumes, almost no binucleated cells were found, indicating cytotoxicity. Taking into account the results obtained on negative control samples, we assume that cyto/genotoxicity was mediated through leachate components rather than through changes in osmolarity. Indeed, drinking water added to cell cultures in volumes up to $1000 \mu \mathrm{L}$ did not induce a marked decrease in binucleated cells. We cannot make any firm conclusions about MN frequency in samples with only a few binucleated cells.
High micronucleus frequency was also found in lymphocytes treated with $100 \mu \mathrm{L}$ of well water (23 MNs per 1000 binucleated cells). Similar to leachate, higher volumes of well water $(>1200 \mu \mathrm{L})$ led to a marked decrease in binucleated cells, most probably due to toxicity. This is in accordance with an earlier study on Vicia faba (11) in which apoptosis was induced by genotoxic agents in water of wells located in the vicinity of dumps.

PI showed more or less the same behaviour as MN frequency. It somewhat increased in samples treated with $400 \mu \mathrm{L}$ and $800 \mu \mathrm{L}$ of leachate and decreased at volumes $\geq 1000 \mu \mathrm{L}$. This may again indicate toxicity and inhibition of cell division at higher volumes.

Table 1 Results of the physicochemical characterisation of leachate, well water, and tap water

\begin{tabular}{|c|c|c|c|c|c|c|c|c|}
\hline Samples & $\mathrm{pH}$ & $\mathrm{O}_{2} / \%$ & $\begin{array}{l}\mathrm{COD} / \\
\mathrm{mg} \mathrm{L}^{-1}\end{array}$ & $\begin{array}{l}\mathrm{HCO}_{3}^{-/} \\
\mathrm{mg} \mathrm{L}^{-1}\end{array}$ & $\begin{array}{l}\mathrm{Ca}^{2+} / \\
\mathrm{mg} \mathrm{L}^{-1}\end{array}$ & $\begin{array}{l}\mathrm{Mg}^{2+} / \\
\mathrm{mg} \mathrm{L}^{-1}\end{array}$ & $\begin{array}{c}\mathrm{Cl}^{-/} / \\
\mathrm{mg} \mathrm{L}^{-1}\end{array}$ & $\begin{array}{c}\text { Conductivity / } \\
\mu \mathrm{S} \mathrm{cm} \mathbf{c m}^{-1}\end{array}$ \\
\hline Leachate & 8.07 & 8.8 & 5866.67 & 4514 & 352.704 & 203.674 & 7668 & 15170 \\
\hline Well 1 & 7.34 & 38 & 2623.33 & 128.1 & 184.368 & 114.982 & 1136 & 4630 \\
\hline $\begin{array}{l}\text { Drinking } \\
\text { water }\end{array}$ & 7.08 & 76 & - & 42.7 & 8.02 & 7.29 & 78.8 & - \\
\hline $\begin{array}{l}\text { Moroccan } \\
\text { Standard }\end{array}$ & 6.5 to 8.5 & 70 & 25 & - & - & 50 & 750 & 2700 \\
\hline
\end{tabular}

COD - chemical oxygen demand

Table 2 Results of the cytogenetic tests

\begin{tabular}{|c|c|c|c|c|c|c|c|c|c|c|c|}
\hline Samples & $\begin{array}{c}\text { Volume } \\
\text { added } \\
\text { to the } \\
\text { cultures / } \\
\mu \mathrm{L}\end{array}$ & $\begin{array}{c}\text { No. of } \\
\text { binucleated } \\
\text { cells } \\
\text { analysed }\end{array}$ & $\begin{array}{c}\text { Total } \\
\text { No. of } \\
\text { MN }\end{array}$ & $\begin{array}{c}\text { MN } \\
\text { frequency }\end{array}$ & $\begin{array}{l}\text { No. of } \\
\text { cells } \\
\text { with } \\
\text { MN }\end{array}$ & $\begin{array}{c}\text { Cells } \\
\text { with } 1 \\
\text { MN }\end{array}$ & $\begin{array}{c}\text { Cells } \\
\text { with } 2 \\
\text { MNs }\end{array}$ & $\begin{array}{c}\text { Cells } \\
\text { with } 3 \\
\text { MNs }\end{array}$ & $\begin{array}{c}\text { Cells } \\
\text { with } 4 \\
\text { MNs }\end{array}$ & $\begin{array}{c}\text { Cells } \\
\text { with } 5 \\
\text { MNs }\end{array}$ & PI \\
\hline Control & 0 & 1007 & 4 & 0.004 & 4 & 4 & 0 & 0 & 0 & 0 & 1.062 \\
\hline \multirow{7}{*}{ Leachate } & 100 & 1000 & 3 & 0.003 & 3 & 0 & 0 & 0 & 0 & 0 & 1.063 \\
\hline & 200 & 163 & 15 & 0.055 & 8 & 4 & 2 & 1 & 0 & 1 & 1.009 \\
\hline & 400 & 1072 & 47 & 0.044 & 36 & 25 & 11 & 0 & 0 & 0 & 1.113 \\
\hline & 800 & 1000 & 48 & 0.048 & 41 & 34 & 7 & 0 & 0 & 0 & 1.036 \\
\hline & 1000 & 13 & 9 & 0.69 & 4 & 1 & 1 & 2 & 0 & 0 & 1.001 \\
\hline & 1200 & 9 & 2 & 0.44 & 2 & 2 & 0 & 0 & 0 & 0 & 1.003 \\
\hline & 1500 & 22 & 4 & 0.09 & 3 & 1 & 0 & 1 & 0 & 0 & 1.004 \\
\hline \multirow{7}{*}{$\begin{array}{l}\text { Water } \\
\text { from the } \\
\text { well }\end{array}$} & 100 & 1117 & 24 & 0.02 & 23 & 22 & 1 & 0 & 0 & 0 & 1.082 \\
\hline & 200 & 1000 & 11 & 0.011 & 11 & 11 & 0 & 0 & 0 & 0 & 1.025 \\
\hline & 400 & 1048 & 4 & 0.004 & 4 & 4 & 0 & 0 & 0 & 0 & 1.043 \\
\hline & 800 & 1010 & 10 & 0.001 & 10 & 10 & 0 & 0 & 0 & 0 & 1.038 \\
\hline & 1000 & 108 & 7 & 0.065 & 6 & 5 & 1 & 0 & 0 & 0 & 1.007 \\
\hline & 1200 & 180 & 7 & 0.039 & 4 & 1 & 0 & 0 & 1 & 0 & 1.006 \\
\hline & 1500 & 163 & 1 & 0.006 & 1 & 1 & 0 & 0 & 0 & 0 & 1.011 \\
\hline \multirow{4}{*}{$\begin{array}{l}\text { Drinking } \\
\text { Water } \\
\text { (negative } \\
\text { control) }\end{array}$} & 100 & 1000 & 5 & 0.006 & 4 & 3 & 1 & 0 & 0 & 0 & 1.104 \\
\hline & 400 & 661 & 5 & 0.007 & 5 & 5 & 0 & 0 & 0 & 0 & 1.018 \\
\hline & 1000 & 1010 & 14 & 0.014 & 13 & 12 & 1 & 0 & 0 & 0 & 1.052 \\
\hline & 1500 & 609 & 9 & 0.015 & 9 & 9 & 0 & 0 & 0 & 0 & 1.013 \\
\hline
\end{tabular}


Table 3 Regression analysis of the proliferation indices and MN frequency

\begin{tabular}{lcccc}
\hline & Factors tested & R & F & P \\
\hline \multirow{3}{*}{ Proliferation Index } & Leachate/ Well Water & 0.71 & 6.1370 & $<0.05$ \\
& Leachate/Tap Water & 0.25 & 0.3837 & NS \\
& Well Water/Tap Water & 0.47 & 1.7040 & NS \\
\hline \multirow{2}{*}{$\begin{array}{l}\text { Frequency of } \\
\text { micronuclei }\end{array}$} & Leachate/Well Water & 0.88 & 20.943 & $<0.01$ \\
& Leachate/Tap Water & 0.43 & 1.3866 & NS \\
\hline
\end{tabular}

$N S$ - non significant

In general, PI fluctuated a lot, and the differences between treatments were not clear (Table 2). Regression analyses showed that lymphocyte response was significantly different only between leachate and well water (Table 3). There was no significant correlation between MN frequency and PI.

It appears that the addition of volumes up to $1000 \mu \mathrm{L}$ is suitable for (geno)toxicity assessment of water. Our findings for dump leachate and ground water are in accordance with several other studies (6, $9,12,20,26,27)$. Sang et al. (26) found cytogenetic damage in root tips of Hordeum vulgare exposed to municipal landfill leachate. Leachate decreased the mitotic index and significantly increased MN frequencies in a dose- and time-dependent manner. Sang and Li (20) had similar findings for Vicia faba root tips. Lah et al. (12) recently applied an integrated physico-chemical-biological approach to evaluate genotoxicity of soil in vitro. They performed the alkaline comet assay in Caco-2 and HepG2 cells exposed to water soil leachates. Samples were evaluated for genotoxicity with parallel Ames and Tradescantia micronucleus tests. Genotoxicity of all water soil leachates was demonstrated with the comet assay, but the Ames test yielded no positive results. The Tradescantia micronucleus assay showed increased MN frequency in half the samples. The authors concluded that the comet assay was the most sensitive assay, followed by the micronucleus test.

In conclusion, our in vitro study on human white blood cells confirms the genotoxic risk of pollutants present in leachates and well water collected near the Settat dump. It also demonstrates the usefulness of combining physicochemical analysis with cytogenetic methods in order to better understand the toxicity of chemical pollutants and their influence on health. Physicochemical analysis is necessary to determine the nature of the pollutants and to propose a suitable method of water treatment whereas cytogenetic analysis is useful to detect genotoxic effects of the complex mixture that constitutes the leachate. Indeed, the effect of chemical interactions and the influence of complex matrices on toxicity cannot be determined from chemical tests alone.

\section{REFERENCES}

1. Cabrera GL, Rodriguez DMG. Genotoxicity of leachates from a landfill using three bioassays. Mutat Res 1999;426:20710

2. Jupsin H, Praet E, Vasel J-L. Caractérisation des lixiviats de CET et modélisation de leur évolution [Sanitary landfill characterization and modelisation of their evolution, in French]. In: Proceedings of the International Symposium on Environmental Pollution Control and Waste Management, 7-10 January 2002, Tunis (EPCOWM'2002) [displayed 25 May 2009]. Available at http://www.geocities.jp/epcowmjp/ EPCOWM2002/884-896Vasel.pdf

3. Christensen H, Kjeldsen P, Albrechtsen H, Heron G, Nielsen PH, Bjerg PL, Holm PE. Attenuation of landfill leachate pollutants in ground water. Crit Rev Environ Sci Technol 1994;24:119-202.

4. Halim CE, Amal R, Beydoun D, Scott JA, Low G. Evaluating the applicability of regulatory leaching tests for assessing the hazards of $\mathrm{Pb}$-contaminated soils. J Hazard Mater 2005;B120:101-11.

5. Omura M, Inamasu T, Ishinishi N. Mutagenic activity of the leachate of municipal solid waste landfill. Mutat Res 1992;298:125-9.

6. Schrab GE, Brown KW, Donnelly KC. Acute and genetic toxicity of municipal landfill leachate. Water Air Soil Poll 1993;69:99-112.

7. Gonsebatt ME, Salazar AM, Montero R, Díaz Barriga F, Yáñez L, Gómez H, Ostrosky-Wegman P. Genotoxic monitoring of workers at a hazardous waste disposal site in Mexico. Environ Health Persp 1995;103(Suppl 1):111-3.

8. Fang M, Liu D, Kuang Y. Micronucleus effects of refuse leachate on root tip cells of Vicia faba. Chin J Appl Environ Biol 1999;5:574-7.

9. Li G, Sang N, Zhao Y. Micronuclei induced by municipal landfill leachate in mouse bone marrow cells in vivo. Environ Res 2004;95:77-81.

10. Li G, Yun Y, Li H, Sang N. Effect of landfill leachate on cell cycle, micronucleus, and sister chromatid exchange in Triticum saestivum. J Hazard Mater 2008;155:10-6. 
11. Chandra S, Chauhan LK, Pande PN, Gupta SK. Cytogenetic effects of leachates from tannery solid waste on the somatic cells of Vicia faba. Environ Toxicol 2004;19:129-33.

12. Lah N, Vidic T, Glasencnik E, Cepeljnik T, Gorjanc G, Marinsek-Logar R. Genotoxicity evaluation of water soil leachates by Ames test, comet assay, and preliminary Tradescantia micronucleus assay. Environ Monit Assess 2008;139:107-18.

13. Brown KW, Donnelly KC. Mutagenic activity of runoff and leachate water from hazardous waste land treatment. Environ Poll (Series A) 1984;35:229-46.

14. Picado A, Mendonça E, Silva L, Paixão SM, Brito F, Cunha MA, Leitão S, Moura I, Hernan R. Ecotoxicological assessment of industrial wastewaters in Trancão river basin (Portugal). Environ Toxicol 2008;23:466-72.

15. Association Française de Normalisation (AFNOR). Qualité de l'eau. Tome 1: Terminologie, échantillonnage et évaluation des méthodes [Water quality. Volume 1: Terminology, sampling and evaluation methods; in French]. $6^{\text {th }}$ ed. Paris: AFNOR; 2001.

16. Rodier J, Bazin C, Broutin JP, Chambon P, Champsaur H, Rodi L, editors. L'analyse de l'eau: Eaux naturelles, eaux résiduaires, eaux de mer: chimie, physico-chimie, microbiologie, biologie, interprétation des résultats [An analysis of water: natural waters, wastewater, water wednesday, in French]. $8^{\text {th }}$ ed. Paris: DUNOD; 1996.

17. Fenech M, Morley AA. Measurement of micronuclei in lymphocytes. Mutat Res 1985;147:29-36.

18. Fenech M. The cytokinesis-block micronucleus technique: a detailed description of the method and its application to genotoxicity studies in human populations. Mutat Res 1993;285:35-44.

19. Titenko-Holland N, Windhan G, Kolachana P, Reinish F, Paravatham S, Osorio AM. Genotoxicity of malathion in human lymphocytes assessed using the micronucleus assay in vitro and in vivo: a study of malathion-exposed workers. Mutat Res 1997;388:85-95.

20. Sang N, Li G. Genotoxicity of municipal landfill leachate on root tips of Vicia faba. Mutat Res 2004;560:159-65.

21. Kjeldsen P. Groundwater pollution source characterization of an old landfill. J Hydrol 1993;142:349-71.

22. Bonassi S, Znaor A, Ceppi M, Lando C, Chang WP, Holland N, Kirsch-Volders M, Zeiger E, Ban S, Barale R, Bigatti MP, Bolognesi C, Cebulska-Wasilewska A, Fabianova E, Fucic A, Hagmar L, Joksic G, Martelli A, Migliore L, Mirkova E, Scarfi MR, Zijno A, Norppa H, Fenech M. An increased micronucleus frequency in peripheral blood lymphocytes predicts the risk of cancer in humans. Carcinogenesis 2007;28:625-31.

23. Durgo K, Oreščanin V, Lulic் S, Kopjar N, Želježić D, Franekić Čolić J. The assessment of genotoxicity effects of wastewater from a fertilized factory. J Appl Toxicol 2008;29:42-51.

24. Fenech M. Cytokinesis-block micronucleus assay evolves into a "cytome" assay of chromosomal instability, mitotic dysfunction and cell death. Mutat Res 2006;600:58-66.

25. Roser S, Pool-Zobel BL, Rechkemmer G. Contribution of apoptosis to responses in the comet assay. Mutat Res 2001;497:169-75

26. Sang N, Li G, Xin X. Municipal landfill leachate induces cytogenetic damage in root tips of Hordeum vulgare. Ecotox Environ Safety 2006;63:469-73.

27. Baun A, Ledin A, Reitzel LA, Bjerg PL, Christensen TH. Xenobiotic organic compounds in leachates from ten Danish MSW landfills - chemical analysis and toxicity tests. Water Res 2004;38:3845-58. 
Sažetak

\section{IN VITRO ISPITIVANJE GENOTOKSIČNOSTI PROCJEDNIH VODA IZ ODLAGALIŠTA OTPADA GRADA SETTATA U MAROKU}

Sve veća uporaba i stvaranje procjednih voda iz nekontroliranih odlagališta krutoga otpada postali su ozbiljna prijetnja vodenom okolišu. Cilj je ovog istraživanja bio procijeniti genotoksičnost takvih procjednih voda te podzemnih voda uzorkovanih iz bunara u blizini odlagališta otpada grada Settata u Maroku. U tu svrhu rabili smo mikronukleusni test in vitro i usporedno istražili kinetiku proliferacije limfocita periferne krvi zdrave dobrovoljne ispitanice. Osim toga, analizirano je više fizikalno-kemijskih parametara (nitrati, ortofosfati, nitriti, $\mathrm{pH}$, otopljeni kisik, kemijska potrošnja kisika, temperatura, zamućenost vode). Te su analize procjednih voda i vode iz bunara pokazale brojna odstupanja od propisanih marokanskih standarda. Usto je u limfocitima izlaganim ovim vodama utvrđena i povišena učestalost mikronukleusa. Preliminarni nalazi pokazuju da su obje vrste voda genotoksične i da su mogući izvor rizika za okoliš i ljudsko zdravlje.

KLJUČNE RIJEČI: fizikalno-kemijska svojstva, indeks proliferacije, limfociti, mikronukleusni test, toksičnost, učinak ovisan o dozi

CORRESPONDING AUTHOR:

Professor Abderraouf Hilali

Hassan I University, Faculty of Science and Technology

P. O. Box 577, 26000 Settat, Morocco

E-mail: hilalia@hotmail.com 